\title{
PENERAPAN TEKNOLOGI INFORMASI UNTUK PROSES PRODUKSI DAN PEMASARAN PRODUK BATIK DAN BORDIR DI PAKISAJI, KAB. MALANG
}

\author{
Dwi Puspitasari ${ }^{\# 1}$, Yan Watequlis S. ${ }^{\# 2}$, Atiqah Nurul Asri ${ }^{\# 3}$, Mungki Astiningrum ${ }^{\# 4}$, Yuri \\ Ariyanto $^{\# 5}$ \\ \# Jurusan Teknologi Informasi, Politeknik Negeri Malang \\ Jl. Soekarno-Hatta No. 9 PO BOX 04 Malang 65141 Jawa Timur, Indonesia

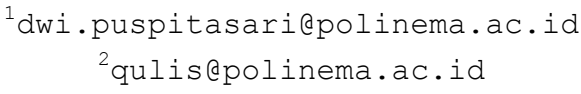

abstrak

Tuntutan hidup yang semakin tinggi dibutuhkan sebuah cara untuk membantu mengatasi permasalahan yang terkait dengan perekonomian mendorong para ibu rumah tangga di Desa Pakisaji, Kabupaten Malang untuk membentuk kelompok usaha batik tulis "Ron Tuwuh" dan kelompok usaha bordir "Prohanji Bordir" yang merupakan teknik pembuatan kain bergambar. Namun, dalam wirausaha yang baru dirintis ini memiliki beberapa kendala seperti modal peralatan produksi yang belum mencukupi, keterbatasan sarana produksi, inovasi desain, desain yang masih manual serta sumber daya pemasaran yang masih terbatas. Mitra yang bekerjasama dalam kegiatan ini akan menerima pelatihan dan pendampingan mendesain batik dan bordir menggunakan teknologi komputer, pembuatan website sebagai media pemasaran juga bantuan alat dan bahan tambahan. Luaran yang didapatkan dalam kegiatan ini adalah website pemasaran yang diharapkan dapat membantu pemasaran produk kelompok usaha. Selain itu dengan kegiatan ini diharapkan anggota kelompok usaha mendapatkan tambahan pengetahuan dan keterampilan dalam mendesain batik dan border menggunakan perangkat komputer.

Kata Kunci —batik, bordir, kelompok usaha, pelatihan, pemasaran.

\section{PENDAHULUAN}

Batik telah ditetapkan sebagai warisan budaya Indonesia, tidak heran bila kreasi kerajinan tersebut kini mulai dicintai seluruh lapisan masyarakat dan penggunaan batik di dalam negeri dan luar negeri pun semakin meluas baik untuk pakaian formal maupun informal. Perkembangan batik di tanah air yang begitu pesat telah menciptakan ceruk pasar yang sangat luas dan menyebabkan pasar batik di Indonesia dipenuhi dengan produk batik printing yang terkadang melupakan seni dan falsafah asli batik. Selain itu ada juga bordir yang merupakan salah satu warisan artefak budaya yang berpotensi untuk dikembangkan menjadi industry kreatif [1]. Bordir sendiri sebetulnya juga termasuk ke dalam kerajinan tangan, dimana dengan bordir manual seluruh pengerjaannya mengandalkan ketrampilan tangan [2].

Saat ini industri pembuatan batik dan bordir sudah merambah sebagai bagian dari Industri Kecil Menengah (IKM). Hal ini ditindaklanjuti oleh kelompok ibu-ibu PKK Desa Pakisaji, Kabupaten Malang sebagai peluang untuk melakukan pemberdayaan ekonomi melalui usaha kecil di bidang pembuatan batik tulis dan bordir. Batik dapat dijadikan andalan bagi industri dan perekonomian yang dapat meningkatkan penghasilan bagi seluruh pemangku kepentingan di Tanah Air. Sedangkan bordir merupakan komoditas yang saat ini banyak diminati oleh masyarakat terutama penggemar mode.

Ron Tuwuh adalah sebuah Usaha Mikro, Kecil dan Menengah (UMKM) yang berlokasi di Pakisaji, Kabupaten Malang. Nama "Ron Tuwuh" sendiri adalah bahasa jawa yang memiliki arti "Daun yang Bertumbuh". UMKM Ron Tuwuh diinisiasi oleh Bu Wiji sekitar bulan Maret 2017 dengan target para ibu rumah tangga anggota PKK di kawasan Pakisaji. Bu Wije memulai UMKM ini setelah mendapat pelatihan dari Disperindag pada tahun 2016. Selain kelompok batik ini, ada juga usaha bordir yang bernama ProHanji yang berfokus untuk mendesain bordir yang akan digunakan untuk kerjinan.

Kedua kelompok ini masing-masing berfokus pada satu bidang yaitu batik ataupun bordir. Kedua kelompok ini dibentuk dengan tujuan untuk meningkatkan pendapatan masyarakat melalui kewirausahaan dalam bidang kerajinan batik tulis dan bordir.

Dalam kelompok wirausaha yang baru dirintis ini masih memiliki banyak kendala yang dihadapi yaitu :

1) Modal peralatan produksi, dimana peralatan produksi bordir masih belum menggunakan mesin yang menggunakan komputer sehingga 
kualitas hasil bordir belum terlalu baik. Sedangkan pada kelompok batik masih memerlukan kompor dan panci besar untuk proses pembersihan malam.

2) Keterbatasan sarana produksi, dimana sarana membatik seperti canting masih menggunakan peralatan tradisional yang manual dengan pemanas kompor. Hal ini menyebabkan proses membatik memerlukan waktu yang lebih lama.

3) Desain masih manual, dimana kedua kelompok masih melakukan pembuatan sketsa gambar secara manual, sehingga kualitas gambar yang dihasilkan masih sangat rendah.

4) Keterbatasan inovasi desain, dimana pengetahuan tentang desain batik dan bordir yang masih minim di antara para anggotanya sehingga diperlukan pengetahuan tentang berbagai jenis desain batik dan bordir.

5) Sumber daya pemasaran, dimana setiap kelompok masih belum memiliki personil yang memiliki keahlian dalam bidang pemasaran. Mengingat mayoritas anggota kelompok masih kurang familiar dengan teknologi informasi sehingga pemasaran menggunakan media online masih belum dilakukan.

Berdasarkan dari identifikasi permasalahan diatas maka pada pengabdian kepada masyarakat kali ini ditawarkan solusi untuk mengatasi persoalan yang muncul. Solusi yang diusulkan adalah:

1. Melakukan pembuatan kompor elektrik yang menggunakan energi listrik sebagai pemanas malam. Perencanaan awal adalah melakukan pembuatan alat canting elektrik. Hal ini dikarenakan menggunakan canting elektrik membuat pekerjaan menjadi lebih efisien, hemat waktu, hemat biaya, dan sangat mudah, semudah menulis menggunakan spidol atau bolpoin di atas kain. Mata canting (cucuk) dapat diganti-ganti sesuai dengan kebutuhan saat bekerja dan malam/lilin dapat langsung tembus pada belakang kain yang dibatik tanpa harus di bolak balik sehingga dapat menghemat waktu pengerjaan khususnya untuk pembuatan batik yang dua muka. Canting elektrik lebih mudah di gunakan, terutama bagi para pemula yang tidak mau terkena asap dari kompor yang digunakan untuk mencairkan lilin atau malam [3]. Dengan canting elektrik mengerjakan batik tulis menjadi lebih mudah, meskipun harus tetap telaten dan hati-hati. Sumber energi canting elektrik adalah listrik yang masuk terlebih dahulu ke dalam sebuah adaptor. Adaptor yang digunakan sudah dirancang khusus agar dapat mengalirkan listrik pada beberapa canting sekaligus. Cara seperti ini juga mampu menekan pengeluaran daripada harus membeli minyak tanah sebagai bahan bakar kompor [4]. Akan tetapi pada saat survei di tempat PKM pihak kelompok menyatakan bahwa mereka sudah pernah menggunakan canting elektrik dan ternyata mengalami banyak kendala seperti, canting rawan buntu sehingga mudah rusak selain itu penggunaan lebih sulit dibandingkan dengan canting yang biasa. Oleh sebab itu pada pelaksanaan PKM pembuatan canting elektri diganti dengan pembuatan tungku elektrik. Tungku elektrik yang dibuat mereferensi dari tungku elektrik di pembuatan rokok.

2. Melakukan pelatihan penggunaan perangkat lunak desain, dimana dua jenis perangkat lunak yang biasa digunakan untuk mendesain khususnya batik dan bordir akan diperkenalkan. Yang pertama menggunakan perangkat lunak khusus untuk desain batik, yaitu jBatik. Dengan software design jBatik, proses membuat polapola batik dapat dilakukan dengan memetakan pola-pola batik secara matematis yang kemudian akan diterjemahkan dalam bentuk pola-pola batik digital oleh software batik yang satu ini. Bahkan hanya dengan satu pola jika dikombinasikan dengan pola-pola yang lain di jBatik bisa menghasilkan pola batik baru. Yang kedua menggunakan photoshop, dimana membuat sketch untuk motif design bordir menggunakan Adobe photoshop brush plugin sudah banyak dilakukan oleh banyak orang. Motif design bordir apapun dapat dengan mudah dibuat hanya dengan beberapa klik menggunakan mouse. Dengan cara ini memberikan kita lebih bebas untuk mengatur warna, mengatur ukuran ataupun merubah posisi sesuai keinginan kita tanpa harus memerlukan kertas, pensil, penghapus, pewarna atau alat tulis lainnya. Akan tetapi pada saat pelaksanaan pihak PKM mengalami kesulitan dengan menggunakan jBatik, oleh karena itu digantikan dengan menggunakan Corel Draw.

3. Melakukan pembuatan website produk batik dan bordir, merupakan website yang digunakan untuk menampilkan produk-produk batik dan bordir yang dihasilkan oleh kedua kelompok. Selain itu juga menampilkan pengetahuan umum tentang batik dan bordir. Diharapkan dengan pembuatan website pemasaran dapat membantu kelompok usaha untuk mempromosikan produk yang dihasilkan dan dapat memperluas pemasaran produk [5].

4. Melakukan pelatihan pemasaran pada media online, dimana akan melakukan pelatihan tentang cara pemasaran melalui media internet serta pelatihan tentang cara pengisian website produk batik dan bordir. 


\section{TARGET DAN LUARAN}

Target dari kegiatan ini adalah mitra bisa mendesain batik dan bordir menggunakan teknologi komputer, serta bisa memasarkan produk batik dan bordir. Selain itu memberikan bantuan berupa tambahan perlatan batik seperti kompor listrik untuk melelehkan lilin, tambahan canting, kain, lilin, pewarna, pengunci warna. Untuk kebutuhan bordir, tambahan alat yang diberikan yaitu midangan, benang serta perlengkapan jarum.

Target ini akan diupayakan tercapai dengan dilakukan serangkaian kegiatan pelatihan, pembuatan pembuatan desain batik menggunakan perangkat corel draw, pembuatan tamplate desain batik, dan pelatihan pengoperasian website pemasaran. Sehingga setelah pelatihan para anggota kelompok usaha bisa mendesain batik dan border sendiri. Serta pembuatan website pemasaran produk batik dan bordir. Luaran dari kegiatan ini adalah anggota kelompok usaha mampu mendesain batik menggunakan corel draw serta mengoperasikan website pemasaran produk.

TABEL I

TARGET LUARAN PKM

\begin{tabular}{|c|c|c|c|c|}
\hline No & Solusi & Luaran & Spesifikasi & Kuantitas \\
\hline 1 & $\begin{array}{l}\text { Pembuatan } \\
\text { tungku } \\
\text { elektrik }\end{array}$ & $\begin{array}{l}\text { Tungku } \\
\text { elektrik }\end{array}$ & $\begin{array}{l}\text { Bisa di isi } \\
\text { Malam dan isi } \\
\text { tinta cat untuk } \\
\text { melukis (dua } \\
\text { fungsi), Suhu } \\
\text { panas dapat di } \\
\text { atur suhu min } \\
85^{\circ} \mathrm{C} \text { max } \\
107^{\circ} \mathrm{C} \text {, dan } \\
\text { ujung canting } \\
\text { (pena) dapat } \\
\text { di ganti ganti. }\end{array}$ & $\begin{array}{l}10 \text { buah } \\
\text { alat }\end{array}$ \\
\hline \multirow[t]{2}{*}{2} & \multirow{2}{*}{$\begin{array}{l}\text { Pelatihan } \\
\text { desain }\end{array}$} & $\begin{array}{l}\text { Modul } \\
\text { pelatihan }\end{array}$ & $\begin{array}{l}\text { Pelatihan } \\
\text { mendesain } \\
\text { batik dan } \\
\text { bordir dengan } \\
\text { software } \\
\text { Adobe } \\
\text { Photoshop dan } \\
\text { Corel draw. }\end{array}$ & 2 modul \\
\hline & & $\begin{array}{l}\text { Peserta } \\
\text { pelatihan }\end{array}$ & $\begin{array}{l}\text { Peserta dari } 2 \\
\text { kelompok } \\
\text { batik dan } \\
\text { bordir, dimana } \\
\text { masing-masing } \\
\text { diwakili } 10 \\
\text { peserta. }\end{array}$ & $\begin{array}{l}20 \\
\text { peserta }\end{array}$ \\
\hline 3 & $\begin{array}{l}\text { Pembuatan } \\
\text { website } \\
\text { pemasaran }\end{array}$ & $\begin{array}{l}\text { Website } \\
\text { yang } \\
\text { dapat } \\
\text { diakses } \\
\text { dari } \\
\text { internet }\end{array}$ & $\begin{array}{l}\text { Website yang } \\
\text { dapat } \\
\text { menampilkan } \\
\text { produk-produk } \\
\text { batik dan } \\
\text { bordir dari } \\
\text { kedua } \\
\text { kelompok, } \\
\text { serta } \\
\text { menampilkan } \\
\text { pengetahuan } \\
\text { tentang batik } \\
\text { dan bordir. }\end{array}$ & 1 paket \\
\hline
\end{tabular}

\begin{tabular}{|c|c|c|c|c|}
\hline \multirow[t]{2}{*}{4} & \multirow[t]{2}{*}{$\begin{array}{l}\text { Pelatihan } \\
\text { pemasaran }\end{array}$} & $\begin{array}{l}\text { Modul } \\
\text { pelatihan }\end{array}$ & $\begin{array}{l}\text { Pelatihan } \\
\text { pemasaran } \\
\text { yang } \\
\text { mencakup } \\
\text { materi } \\
\text { pemasaran } \\
\text { online dan } \\
\text { pengisian } \\
\text { website } \\
\text { produk batik } \\
\text { dan bordir. } \\
\end{array}$ & 1 modul \\
\hline & & $\begin{array}{l}\text { Peserta } \\
\text { pelatihan }\end{array}$ & $\begin{array}{l}\text { Peserta dari } 2 \\
\text { kelompok } \\
\text { batik dan } \\
\text { bordir, dimana } \\
\text { masing-masing } \\
\text { diwakili } 5 \\
\text { peserta. }\end{array}$ & $\begin{array}{l}10 \\
\text { peserta }\end{array}$ \\
\hline
\end{tabular}

Luaran lain yang dihasilkan adalah artikel ilmiah yang akan dipublikasikan pada jurnal pengabdian masyarakat, dan publikasi kegiatan pada media massa online.

\section{METODE PELAKSANAAN}

Berdasarkan permasalahan yang telah dijabarkan, ada beberapa metode yang digunakan yaitu :

\section{A. Solusi Permasalahan Bidang Produksi}

Pada bidang produksi masalah yang dihadapi adalah tentang kurang efektifnya penggunaan tungku untuk melelehkan lilin pada pembuatan batik serta kurang baiknya hasil desain batik dan bordir menggunakan cara manual

Pendekatan solusi untuk mengatasi permasalahan penggunaan tungku yang menyebabkan lamanya proses produksi batik melalui tahapan-tahapan sebagai berikut :

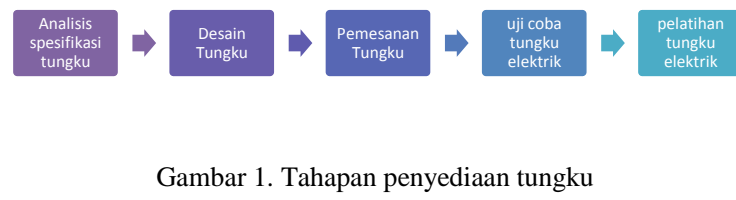

Pada gambar 1. dijelaskan tahapan-tahapan pembuatan tungku elektrik antara lain:

1. Analisis spesifikasi tungku dimulai dengan menganalisis spesifikasi tungku elektrik. Seperti voltage, ukuran, panas, stop kontak, dll.

2. Desain tungku dilakukan oleh pihak yang ahli dalam hai ini mereferensi pada tungku pembuatan rokok dengan pendampingan dari tim pengabdian.

3. Pemesangan tungku pada pihak ahli.

4. Uji coba tungku elektrik dilakukan dengan mencoba alat tersebut untuk membatik pada kain putih yang telah disediakan.

5. Pelatihan pemakaian canting elektrik didampingi oleh tenaga ahli pembatik bersama tim pengabdian. 
Banyak jenis tungku listrik yang bisa digunakan untuk melelehkan lilin batik. Akan tetapi yang diinginkan oleh kelompok usaha batik Ron Tuwuh adalah tungku yang ringan, mampu menghasilkan panas yang pas dan tidak memerlukan daya listrik yang besar. Maka Tim PKM melakukan analisis dan milih kompor dengan spesifikasi sebagai berikut.

TABEL II

SPESIFIKASI TUNGKU LISTRIK

\begin{tabular}{|c|c|c|c|}
\hline Bodi & Berat & Daya & Keterangan \\
\hline Aluminium & $800 \mathrm{gr}$ & 125 Watt & $\begin{array}{lr}\text { Elemen } & \text { pemanas } \\
\text { double } & \text { plat, } \\
\text { dudukan } & \text { gerabah } \\
\text { untuk } & \text { peredam } \\
\text { panas } & \end{array}$ \\
\hline
\end{tabular}

Tungku listrik yang dimaksud adalah seperti berikut.

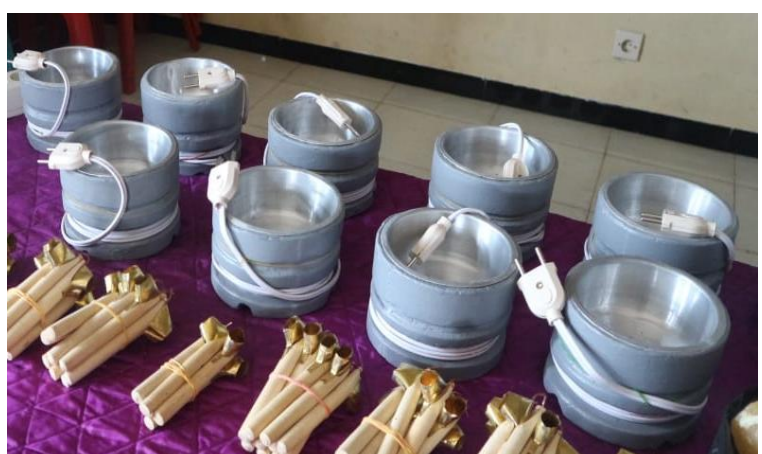

Gambar 2. Tungku listrik untuk melelehkan lilin batik

Disisi lain, dalam keterbatasan sarana dari kelompok usaha, Tim Pengabdian Masyarakat memberikan bantuan berupa tambahan peralatan batik seperti kompor listrik untuk melelehkan lilin, tambahan canting, kain, lilin, pewarna, pengunci warna. Untuk kebutuhan bordir, tambahan alat yang diberikan yaitu midangan, benang serta perlengkapan jarum.

$$
\text { TABEL III }
$$

DAFTAR BANTUAN ALAT DAN BAHAN

\begin{tabular}{|l|l|l|}
\hline No & \multicolumn{1}{|c|}{ Nama Alat/Bahan } & \multicolumn{1}{c|}{ Jumlah } \\
\hline 1. & Tungku elektrik & 10 buah \\
\hline 2. & Canting berbagai ukuran & 200 buah \\
\hline 3. & Kain & 20 potong \\
\hline 4. & Malam & $5 \mathrm{~kg}$ \\
\hline 5. & Pewarna 30 macam & @ 10 gr \\
\hline 6. & Pengunci warna & 5 liter \\
\hline 7. & Benang bordir & 20 biji \\
\hline 8. & Alat bordir dan sulam & @ 10 biji \\
\hline
\end{tabular}

Bantuan alat dan bahan diserahkan langsung kepada ketua UKM Batik RonTuwuh.

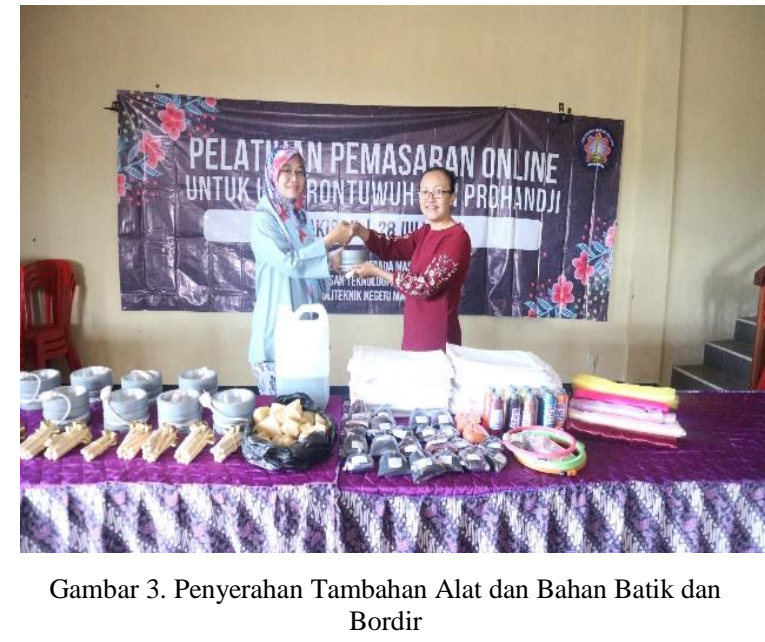

Pada permasalahan produksi yaitu dengan masih manualnya pembuatan desain batik sehingga membutuhkan waktu lama, metode yang diterapkan selanjutnya yaitu dengan memberikan pelatihan desain mengggunakan aplikasi dengan proses pelatihan yang dimulai dari pembuatan modul kemudian dengan mempersiapkan peralatan pelatihan [6]. Pada saat pelatihan, Tim Pengabdian Masyarakat melakukan pendampingan. Gambaran proses pelatihan adalah sebagai berikut.
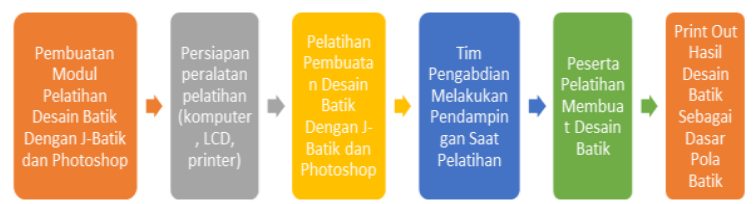

Gambar 4. Tahapan dalam pelatihan desain batik

Pada pelaksanaan pelatihan dilaksanakan oleh tim PKM dengan bantuan mahasiswa Jurusan Teknologi Informasi.

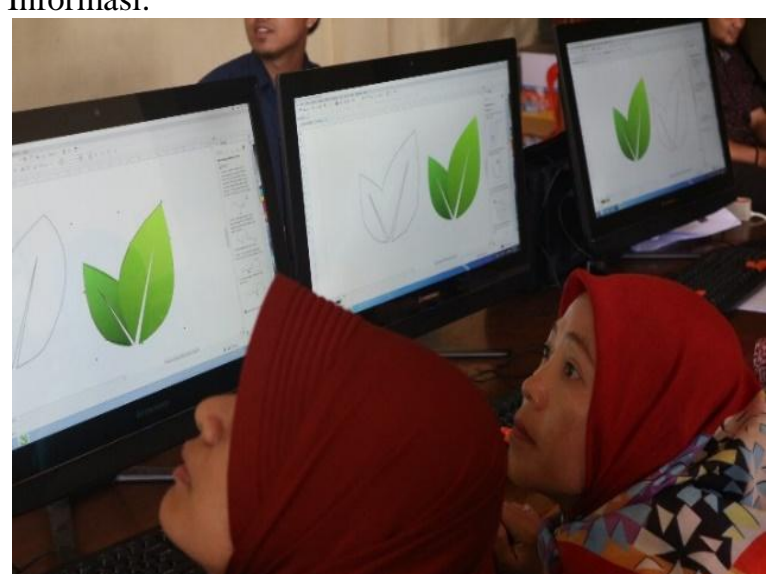

Gambar 5. Pelaksanaan pelatihan desain batik

Gambar 5 menjelaskan tahapan-tahapan dalam melakukan pelatihan desain batik antara lain:

1. Pembuatan modul pelatihan desain batik dengan mencari referensi baik dari pakar desai maupun buku desain baik menggunakan software Coral Draw dan photoshop. 
2. Persiapan peralatan pelatihan dimulai dengan menyiapkan komputer yang akan digunakan dan menginstall software yang dibutuhkan, beserta LCD yang akan digunakan sebagai presentasi dan printer.

3. Pelatihan pembuatan desain batik dengan Corel Draw dan photoshop dilakukan oleh tim pengabdian dengan menggunakan modul yang telah dibuat.

4. Pada saat proses pelatihan berlangsung tim pengabdian melakukan pendampingan pada peserta pelatihan sehingga jika ada kesulitan dalam penggunaan software tersebut dapat cepat teratasi.

5. Setiap peserta pelatihan mendapatkan tugas membuat desain menggunakan software yang telah diberikan dengan mengikuti langkahlangkah percobaan dari modul pelatihan. Setelah tugas yang diberikan selesai peserta mengeprint desain tersebut dan menggunakannya sebagai sketsa membatik.

\section{B. Evaluasi Solusi Bidang Produksi}

Evaluasi dilakukan untuk mengetahui hasil dari solusi permasalahan dalam bidang produksi yang telah dilakukan, antara lain:

1. Evaluasi pembuatan tungku elektrik dilakukan untuk mengetahui bagaimana dampak penggunaan alat tersebut dari proses pembatikan apakah mempunyai dampak lebih cepat dari sebelumnya dengan manual dan meminimalkan resiko api dari kompor.

2. Evaluasi pelatihan desain batik dilakukan untuk mengetahui tingkat keefektifan penggunaan dari software desain dalam membantu pembuatan sketsa gambar batik.

\section{Solusi Permasalahan Pemasaran}

Pada bidang pemasaran masalah yang dihadapi adalah tentang kurang efektifnya penggunaan media pemasaran yang ada, hal ini bisa diatasi dengan penggunaan website dan pemasaran dengan media internet [7].

Pendekatan solusi untuk mengatasi permasalahan dalam bidang pemasaran dalam mempopulerkan hasil batik dengan pelatihan website, melalui tahapan-tahapan sebagai berikut:

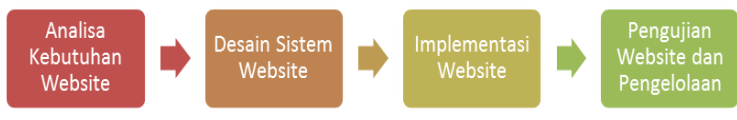

Gambar 6. Tahapan pembuatan website pemasaran

Gambar 6. dijelaskan tahapan-tahapan pembuatan website antara lain:

1. Analisa kebutuhan website dilakukan dengan survey kepada mitra untuk mengetahui konten, fitur yang dibutuhkan dalam mempopulerkan produk.
2. Desain sistem website dimulai dengan membuat database, tabel-tabel yang digunakan dalam pembuatan website.

3. Implementasi website dengan menerbitkan pada domain dan hosting, sehingga mempunyai alamat url.

4. Pengujian website dilakukan dengan mencoba akses alamat url website melalui internet dan pengelolaan website baik dari sisi konten maupun yang lainnya.

Pada pembuatan website pemasaran dihasilkan website yang bisa diakses melalui internet dengan alamat http://batikrontuwuh.epizy.com/.

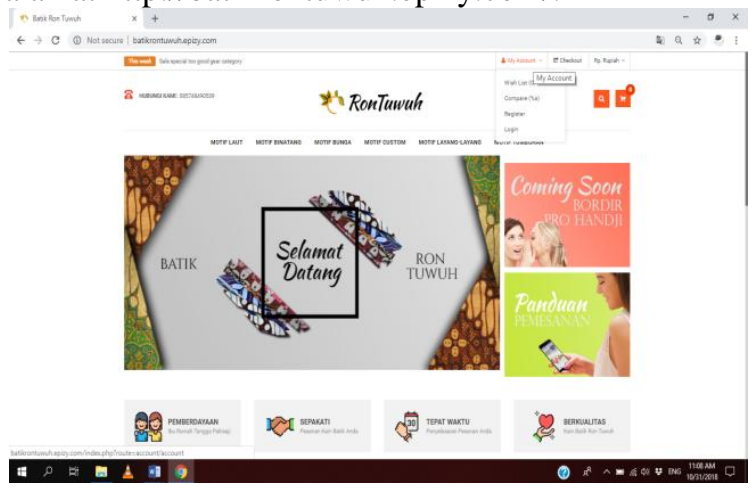

Gambar 7. Tampilan awal website pemasaran batik Ron Tuwuh

Selain pembuatan website pemasaran produk juga dilakukan pendekatan solusi untuk mengatasi permasalahan dalam bidang pemasaran dengan pelatihan pengoperasian website, melalui tahapantahapan sebagai berikut:

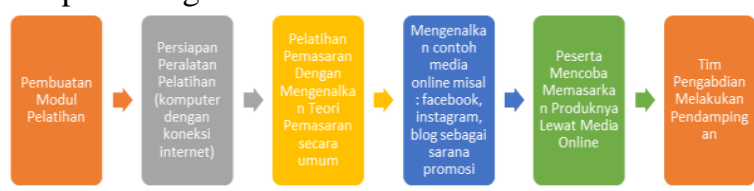

Gambar 8. Tahapan dalam pemasaran melalui media online

Gambar 8 menjelaskan tahapan-tahapan dalam melakukan pelatihan pemasaran pada media online antara lain:

1. Pembuatan modul pelatihan dengan mencari referensi dari buku-buku yang berhubungan dengan pemasaran produk.

2. Persiapan peralatan pelatihan komputer, LCD dan koneksi internet.

3. Pelatihan pemasaran pada media online diberikan dengan mengenalkan teori pemasaran secara umum.

4. Pada proses pelatihan dikenalkan pemanfaatan media online antara lain facebook, instagram dan blog sebagai sarana promosi.

5. Peserta mencoba memasarkan produk melalui media online sesuai dengan materi yang telah di berikan pada modul pelatihan. 


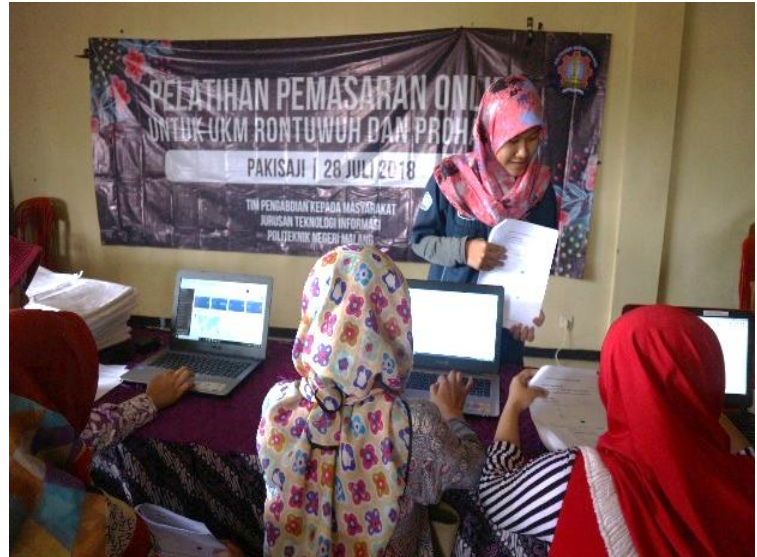

Gambar 9. Pelaksanaan pelatihan pemasaran menggunakan website

\section{Evaluasi Solusi Bidang Pemasaran}

Evaluasi dilakukan untuk mengetahui hasil dari solusi permasalahan dalam bidang pemasaran yang telah dilakukan, antara lain adalah evaluasi pelatihan website dilakukan untuk mengetahui manfaat yang diperoleh pembuatan website dalam mempopulerkan produk yang dihasilkan, serta proses pengelolaan website.

\section{E. Metode Pendekatan Mitra}

Metode yang digunakan dengan melakukan pendampingan pada mitra mulai dari proses produksi sampai proses pemasaran dari batik dan bordir, sehingga mitra mendapatkan manfaat dari program pengabdian ini. Metode pendekatan yang akan dilakukan untuk menyelesaikan permasalahan adalah sebagai berikut. Pertama, metode interaksi sosial di mana menekankan pada hubungan yang baik antara masing-masing pihak (pengusul dan mitra). Pihak pengusul tidak hanya menjalin hubungan dengan ketua kelompok saja tetapi dengan anggota masingmasing mitra dalam melakukan pelatihan dan pendampingan. Selain itu, juga dilakukan pendekatan personal-humanistik yang menekankan pada pengembangan konsep diri smashing-masing anggota. Hal ini meliputi pengembangan proses individu dan membangun serta mengorganisasikan dirinya sendiri. Model memfokuskan pada konsep diri yang kuat dan realistis untuk membantu membangun hubungan yang produktif dengan orang lain dan lingkungannya. Hal ini terkait dengan tujuan diadakannya kegiatan PKM ini yaitu meningkatkan produksi dan pemasaran hasil kain batik dan bordir secara mandiri.

\section{F. Partisipasi Mitra}

Dalam pelaksanaan program dukungan dan partisi mitra sangat penuh. Dari sisi pejabat desa, dukungan dari Kepala Desa Pakisaji sangat besar untuk pelaksanaan program ini dengan menyediakan tempat di Balai Desa untuk kegiatan pengabdian ini .
Kemudian dari sisi peserta dari mitra mendukung pelaksaan program ini dengan kesanggupan mengikuti acara pengabdian sampai selesai.

\section{HASIL DAN PEMBAHASAN}

Kegiatan dilaksankan pada tanggal 23 dan 28 Juli 2018. Pada tanggal 23 Juli merupakan pelatihan desain. Pada pelatihan desain ini, dari Tim Pengabdian Masyarakat Polinema telah menyiampkan komputer yang telah terinstall CorelDraw sebagai alat bantu untuk mendesain baik maupun bordir yang diinginkan.

Persiapan materi juga dilakukan dengan menggunakan sarana dan prasarana modul. Pada prosesnya, pelatihan desain ini dimulai dengan mengikuti arahan dari Tim Pengabdian Masyarakat Polinema sambil mengenalkan fitur dasar dari CorelDraw yang bisa digunakan untuk mendesain. Setelah itu tiap orang melakukan desain sendirisendiri sesuai dengan kreativitas masing-masing.

Kegiatan pada tanggal 28 Juli 2018 dimulai dengan penyerahan bantuan alat dan bahan bordir serta batik yang diwakilkan oleh Ibu Widji selaku ketua dari UMKM Batik Ron Tuwuh. Kegiatan selanjutnya yaitu pelatihan penggunaan website yang telah disiapkan Tim Pengabdian Masyarakat Polinema untuk membantu pemasaran produksi batik.

Dalam kegiatan pelatihan batik ini juga menggunakan sarana dan prasarana modul penggunaaan website. Sistem pelatihan ini dimulai dengan mengikuti modul sambil mengenalkan fiturfitur dasar pada website sehinggan Ibu-Ibu yang mengikuti pelatihan bisa menggunakan website dengan lancar.

Untuk pengukuran ketercapaian tujuan PKM dan mendapatkan respon dari mitra dilakukan pengamatan pada saat pelaksanaan kegiatan serta meminta mitra untuk mengisi kuisioner yang berisi pertanyaan terkait dengan kegiatan PKM.

Berdasarkan hasil kuisioner yang diberikan, serta hasil pengamatan pada setiap tahapan yang telah dilakukan oleh Tim Pengabdian Masyarakat dengan pendampingan mitra dalam pelatihan penerapan teknologi informasi untuk mempermudah usaha yang telah dilakukan oleh ibu-ibu PKK Desa Pakisaji, Kabupaten Malang didapatkan hasil sebagai berikut :

1) Membantu proses produksi pada UMKM Batik Ron Tuwuh dan ProHanji Bordir di Desa Pakisaji Kabupaten Malang dengan memberikan bantuan berupa tambahan alat dan bahan untuk pengerjaan batik serta bordir pada usaha tersebut

2) Meningkatnya antusiame mitra terhadap efisiensi pekerjaan menggunakan teknologi informasi. Pendekatan mitra yang dilakukan dengan interaksi sosial yang menekankan pada hubungan yang baik antara masing-masing pihak (pengusul dan mitra). Hal ini menimbulkan suatu 
kepahaman yang sama mengenai hubungan yang produktif dengan orang lain dan lingkungannya.

3) Membantu kinerja ibu-ibu PKK Desa Pakisaji, Kabupaten Malang dalam bidang produksi yaitu bagian desain batik. Dalam pelatihannya dapat dipahami bahwa dengan mendesain batik menggunakan aplikasi dan bukannya dengan menggambar manual akan bisa menyelesaikan desain secara keseluruhan dengan lebih efisien.

4) Pemasaran yang dilakukan secara online lebih bisa dijangkau oleh keseluruhan masyarakat. Dengan metode pemasaran sebelumnya yang hanya dari mulut ke mulut bisa menjadi lebih mudah dijangkau oleh banyak orang. Website yang digunakan untuk pemasaran onlinepun bisa diakses dengan mudah melalui komputer ataupun handphone mitra. Dalam pelatihan penggunaan websitepun mitra lebih leluasa mendeskripsikan serta membagikan desain batik ataupun bordir yang pernah dibuat. Namun saat ini website masih belum digunakan secara aktif.

5) Publikasi kegiatan Pengabdian Kepada Masyarakat melalui media online. Sehingga masyarakat umum mengetahui peran Politeknik Negeri Malang dalam peningkatan kehidupan masyarakat. Berita mengenai kegiatan PKM ini dapat dilihat pada halaman http://jti.polinema.ac.id/index.php/2018/09/11/ti m-pengabdian-masyarakat-jurusan-teknologiinformasi-politeknik-negeri-malang-bersamaukm-ron-tuwuh/

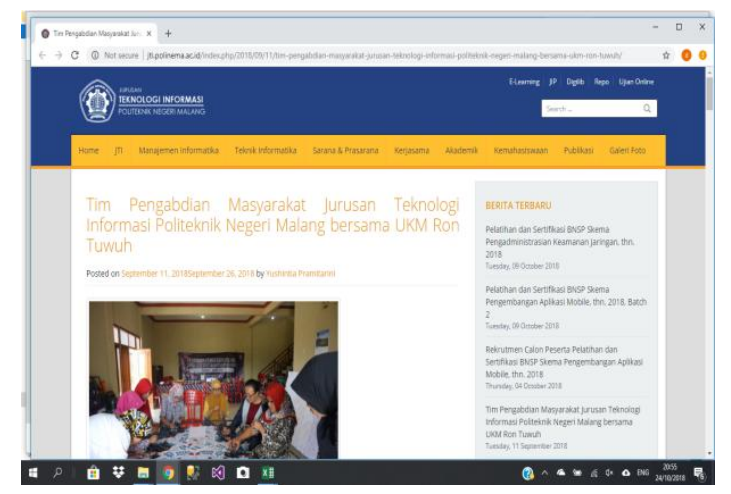

Gambar 10. Publikasi pelaksanaan PKM melalui website Jurusan Teknologi Informasi Politeknik Negeri Malang

\section{KESIMPULAN}

Dalam pelaksanaan kegiatan dari Tim Pengabdian Masyarakat Jurusan Teknologi Informasi Politeknik Negeri Malang dengan menerapkan teknologi informasi pada proses produksi dan pemasaran batik dan bordir di Desa Pakisaji, Kabupaten Malang ini dapat disimpulkan bahwa antuasisme dari ibu-ibu PKK bisa cukup tinggi dengan komunikasi yang baik antara pengusul dan mitra. Diterapkannnya teknologi informasi dalam proses produksi dan pemasaran lebih memudahkan pekerjaan ibu-ibu PKK Desa
Pakisaji, Kabupaten Malang dalam mendesain batik secara keseluruhan. Di sisi lain, untuk proses pemasaran melalui website yang telah dibuat lebih meluaskan area promosi produk dan mengurangi beban tanggung jawab dalam mempromosikan produk secara individu.

\section{UCAPAN TERIMA KASIH}

Ucapan terima kasih ditujukan kepada Politeknik Negeri Malang khususnya P2M yang telah memberikan fasilitas dan dana dalam pelaksanaan kegiatan Pengabdian Kepada Masyarakat ini. Serta kepada anggota kelompok usaha Batik Ron Tuwuh, Bordir Pro Haji serta Bpk. Kepala Desa Pakisaji serta perangkat desanya yang telah membantu dan mendukung kegiatan ini.

\section{DAFTAR PUSTAKA}

[1] Nurficahyanti, Fera. 2015. Model Komunikasi Pemasaran Paguyuban Batik Tulis. Jurnal Komunikasi ASPIKOM, Volume 2 Nomor 5, Juli 2015, hlm 304-313.

[2] Tahwin, Muhammad, 2012. Pengembangan Industri Kecil (Studi Kasus Industri Bordir Kecamatan Sedan Kabupaten Rembang). Jurnal POTENSIO Volume 17 No. 1 Juli 2012.

[3] Ikawanty, Beauty Anggraheny. 2015. Otomatisasi Canting Listrik Untuk Pembuatan Batik Tulis Probolinggo. Prosiding SENTIA 2015, Politeknik Negeri Malang.

[4] Moyoretno, Bambang. Juni 2011. Rancang Bangun Canting Elektrik. Dinamika Kerajinan dan Batik, Vol. 29. Yogyakarta.

[5] Wibisono, Guntur; Susanto, Wahyu Eko. 2015. Perancangan Website Sebagai Media Informasi Dan Promosi Batik Khas Kabupaten Kulonprogo. Jurnal Evolusi - Volume 3 No 2 -2015.

[6] Rif'ah, Mega Inayati; Wibisono, M. Arif. 2016. Pengembangan Computer Aided Design (CAD) Warna Batik. Jurnal Forum Teknik Vol. 37, No. 1, Januari 2016.

[7] Moriansyah, La. 2015. Pemasaran Melalui Media Sosial: Antecedents Dan Consequences. Jurnal Penelitian Komunikasi dan Opini Publik Vol. 19 No.3, Desember 2015: 187-196 